\section{Arkivoc

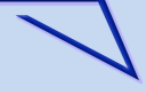

Archive for

Organic Chemistry
The Free Internet Journal

for Organic Chemistry
Paper

Arkivoc 2018, part vii, 0-0

\title{
Synthesis of acylnaphthylamines and their applications in the formation of benzoquinazolines
}

Monika Nowak, ${ }^{* a}$ Emilia Fornal, ${ }^{b}$ Renata Kontek, ${ }^{c}$ Dariusz Sroczyński, ${ }^{\text {d }}$ Andrzej Jóźwiak, ${ }^{a}$ Ewelina Augustowska, ${ }^{a}$ Anna Warpas, ${ }^{b}$ Marta Adamczyk, ${ }^{c}$ and Zbigniew Malinowski*a

aUniversity of Lodz, Faculty of Chemistry, Department of Organic Chemistry,

Tamka 12 Str., 91-403 Lodz, Poland

${ }^{b}$ Medical University of Lublin, Department of Pathophysiology, Jaczewskiego 8b Str., 20-090 Lublin, Poland

'University of Lodz, Faculty of Biology and Environmental Protection, Laboratory of Cytogenetics,

Banacha 12/16 Str., 90-237 Lodz, Poland

'University of Lodz, Faculty of Chemistry, Department of Inorganic and Analytical Chemistry,

Tamka 12 Str., 91-403 Lodz, Poland

Email: monika.nowak@uni.lodz.pl; zbigniew.malinowski@chemia.uni.lodz.pl

\section{Abstract}

The synthesis of acyl N-Boc-1- and N-Boc-2-naphthylamines and their transformation into alkyl substituted benzoquinazolines and benzoquinazolinones through the reaction with formamide or potassium cyanate in the presence of ammonium acetate is described. Presented acyl derivatives were obtained from the reactions of the corresponding lithiated $\mathrm{N}$-Boc naphthylamines with various acetylating agents like $\mathrm{AcCl}, \mathrm{Ac}{ }_{2} \mathrm{O}, \mathrm{AcOEt}, \mathrm{PivCl}$, ${ }^{i} \mathrm{PrCOCl}$ and also Wienreb amides. Biological screening of the potential cytotoxicity on the HT29 cell line and lymphocytes were demonstrated for some benzoquinazoline derivatives.

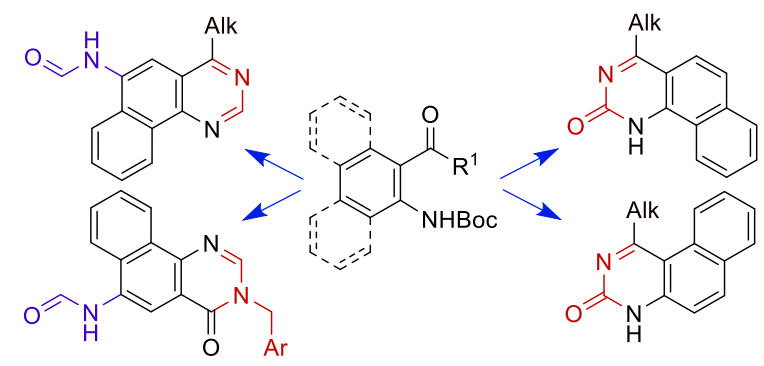

Keywords: Acylation, benzoquinazoline, benzoquinazolinone, Pd-coupling, Cu-coupling, cytotoxicity 


\section{Introduction}

The quinazoline or quinazolinone skeleton is a building block of various alkaloids ${ }^{1,2}$ with diverse biological activities $^{3-5}$ like for example vasicine and vasicinone (active compounds of Justicia athatoda), ${ }^{6-8}$ asperlicins A-E (fungal metabolite components of Aspergillus alliaceus) (10 $^{9}$ or circumdatin $\mathrm{H}$ (from the fungus Aspergillus ochraceus). ${ }^{11}$ It has been shown that e.g. asperlicin and its analogues can act as antagonists of neurotransmitter cholecystokinin (CCK). ${ }^{12}$ Other quinazolinone alkaloids exhibit also anti-inflammatory, ${ }^{13}$ antiviral ${ }^{14}$ and antibacterial activity. ${ }^{15,16}$ Some of quinazoline derivatives have been approved as effective drugs against cancer, ${ }^{17}$ e.g. Gefitinib, ${ }^{18,19}$ Erlotinib ${ }^{20}$ or Ispinesib. ${ }^{21}$ Additionally, aryl- or alkyl- quinazolin-2(1H)-one derivatives are applied e.g. as nonsteroidal anti-inflammatory drugs ${ }^{22}$ (Proquazone) ${ }^{23}$ or in the treatment of cardiovascular diseases (Bemarinone). ${ }^{24,25}$

In the present paper we focused on the synthesis of acyl-N-Boc-aminonaphthalenes and their application for the preparation of new alkylbenzoquinazolines, which constitute a continuation of our work in the field of benzoquinazoline derivatives chemistry and their potential cytotoxic activity. ${ }^{26-28}$

\section{Results and Discussion}

The synthesis of acyl-N-Boc-aminonaphthalenes $\mathbf{2} \mathbf{a}, \mathbf{b}$ and $\mathbf{5} \mathbf{a}, \mathbf{b}$ based on a two-stage procedure consisting of 1 ) in situ generation of lithium carbamates $1 \mathbf{a}$ or $\mathbf{4 a}$ using ${ }^{t} \mathrm{BuLi}$ or $\mathrm{BuLi}^{26,27}$ and then 2 ) their reaction with the selected acylating agents (Scheme 1). At the beginning of our investigations, the behavior of bis-metalated species $1 \mathbf{a}$ and $\mathbf{4 a}$ in the reaction with electrophiles like $\mathrm{AcCl}, \mathrm{Ac} \mathrm{C}_{2} \mathrm{O}, \mathrm{AcOEt}, \mathrm{PivCl}$ and ${ }^{i} \operatorname{PrCOCl}$ was verified. The results are summarized in Table 1.

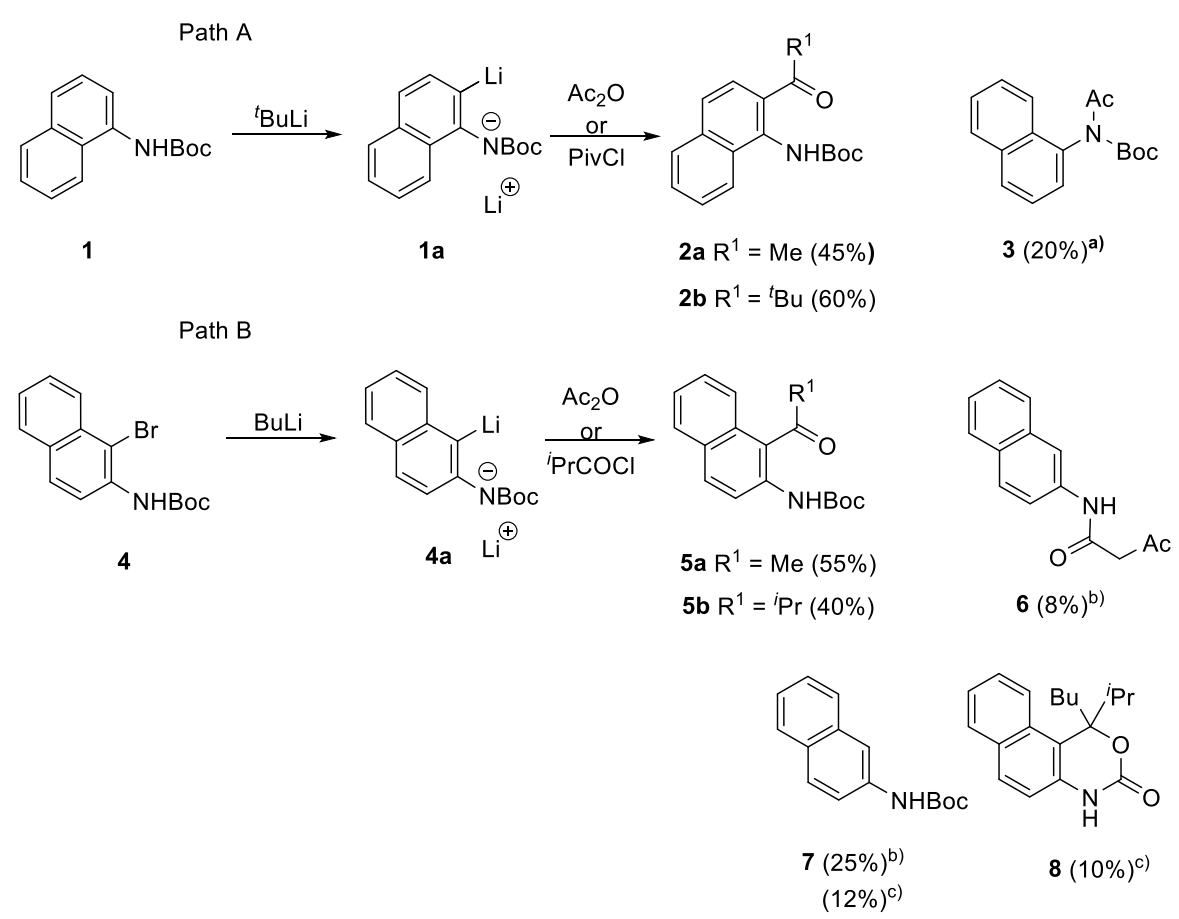

Scheme 1. Synthesis of ketones $\mathbf{2}, \mathbf{5}$. The reaction conditions ${ }^{\text {a) }}$ for the reaction of $\mathbf{1}$ with $\mathrm{Ac}_{2} \mathrm{O},{ }^{\mathrm{b})}$ for the reaction of 4 with $\mathrm{Ac}_{2} \mathrm{O}$, c) for the reaction of 4 with ${ }^{i} \mathrm{PrCOCl}$. 
The use of acetic anhydride for the acylation of 1 or 4 at $-78{ }^{\circ} \mathrm{C}$, turned out to be the most effective for $2 \mathrm{a}$ (45\%) and $\mathbf{5 a}$ (55\%), (Table 1, entries 3 and 11 ). When 1 a was treated with $\mathrm{Ac}_{2} \mathrm{O}$ apart from $2 \mathrm{a}$ also $N$-Ac, $N$-Boc derivative 3 was isolated from the post reaction mixture (Table 1, entry 3). Additionally, we have observed that an increase in the reaction temperature from $-78{ }^{\circ} \mathrm{C}$ up to $-20{ }^{\circ} \mathrm{C}$, (Table 1 , entry 2), resulted in a decrease in yield of $\mathbf{2 a}(20 \%)$. Likewise ineffective was the use of acetyl chloride at $-20{ }^{\circ} \mathrm{C}$ ( $2 \mathrm{a}$ was separated in only $10 \%$ yield, Table 1, entry 1). As can be seen in Table 1, treatment of bis-lithiated species $\mathbf{4 a}$ with acetyl chloride at $-78{ }^{\circ} \mathrm{C}$ gave $\mathbf{5 a}(45 \%$, entry 11$)$, with comparable yield to that of acylation with $\mathrm{Ac}_{2} \mathrm{O}(55 \%$, entry 11$)$ whereas ethyl acetate shown considerably less reactivity at this temperature (10\%, entry 12$)$.

Table 1. Optimization of conditions for the synthesis of acyl derivatives 2, $\mathbf{5}$

\begin{tabular}{|c|c|c|c|c|c|}
\hline \multirow{2}{*}{ 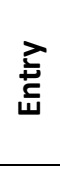 } & \multirow[b]{2}{*}{ Electrophile } & \multirow[b]{2}{*}{$\begin{array}{l}\text { Temp. } \\
\left({ }^{\circ} \mathrm{C}\right)\end{array}$} & \multirow[b]{2}{*}{ Substarte } & \multicolumn{2}{|c|}{ Yield (\%) ${ }^{a}$} \\
\hline & & & & $\begin{array}{c}\text { Products } \\
2,5\end{array}$ & $\begin{array}{c}\text { Other } \\
\text { products }\end{array}$ \\
\hline 1 & $\mathrm{AcCl}$ & -20 & \multirow{4}{*}{1} & $2 a(10)$ & - \\
\hline 2 & $\mathrm{Ac}_{2} \mathrm{O}$ & -20 & & $2 a(20)$ & - \\
\hline 3 & $\mathrm{Ac}_{2} \mathrm{O}$ & -78 & & 2a (45) & $3(20)$ \\
\hline 4 & $\mathrm{AcN}(\mathrm{OMe}) \mathrm{Me}$ & -20 & & $2 a(30)$ & - \\
\hline 5 & $\mathrm{PivCl}$ & -20 & \multirow{5}{*}{1} & $2 b(60)$ & - \\
\hline 6 & $\mathrm{PivCl}$ & -78 & & $\begin{array}{c}\mathbf{2 b} \\
\text { (trace) }\end{array}$ & - \\
\hline 7 & $\begin{array}{c}\text { PivN(OMe)M } \\
\text { e }\end{array}$ & -78 & & $2 b(0)$ & - \\
\hline 8 & $\begin{array}{c}\operatorname{PivN}(\mathrm{OMe}) \mathrm{M} \\
\mathrm{e}\end{array}$ & -20 & & $2 b(30)$ & - \\
\hline 9 & $\begin{array}{c}\text { PivN(OMe)M } \\
\text { e }\end{array}$ & 0 & & $2 b(13)$ & - \\
\hline 10 & $\mathrm{AcCl}$ & -78 & \multirow{4}{*}{4} & $5 a(45)$ & - \\
\hline 11 & $\mathrm{Ac}_{2} \mathrm{O}$ & -78 & & $5 a(55)$ & $\begin{array}{c}6(8) \\
7(25)\end{array}$ \\
\hline 12 & AcOEt & -78 & & $5 a(10)$ & - \\
\hline 13 & $\mathrm{AcN}(\mathrm{OMe}) \mathrm{Me}$ & -20 & & $\begin{array}{c}\mathbf{5 a} \\
\text { (trace) }\end{array}$ & $7(60)$ \\
\hline 14 & ${ }^{i} \mathrm{PrCOCl}$ & -78 & & $5 b(20)$ & $\begin{array}{l}8(5) \\
7(5)\end{array}$ \\
\hline 15 & ${ }^{i} \mathrm{PrCOCl}$ & -20 & 4 & $5 b(40)$ & $\begin{array}{l}8(10) \\
7(12)\end{array}$ \\
\hline 16 & $\begin{array}{c}{ }^{i} \operatorname{PrCON}(\mathrm{OMe}) \\
\mathrm{Me}\end{array}$ & -20 & & $5 b(2)$ & - \\
\hline
\end{tabular}

Reaction conditions: organolithium compound ( 2 hours, $-20^{\circ} \mathrm{C}$ ), 1 equiv. of electrophile ( 2 hours, temperature described in Table 1, entry 1-16).

a Isolated yield 
In case of the synthesis of acyl derivatives $\mathbf{2} \mathbf{b}, \mathbf{5} \mathbf{b}$ the best results were achieved employing pivaloyl or 2methylpropanoyl chloride at $-20^{\circ} \mathrm{C}(\mathbf{2 b}(60 \%), 5 \mathbf{b}(40 \%)$, Table 1 , entries 5,15$)$. When the reaction temperature was decreased from $-20{ }^{\circ} \mathrm{C}$ to $-78{ }^{\circ} \mathrm{C}$, yields of both acetyl derivatives $\mathbf{2} \mathbf{b}$, $\mathbf{5 b}$ were lower (Table 1 , entries 6,14 ). Additionally, the decrease in the reaction temperature resulted also in reduced yields of side products 7,8 accompanying the formation of $\mathbf{5 b}$, from $12 \%(7), 10 \%(8)$ at $-20{ }^{\circ} \mathrm{C}$ to about $5 \%(7,8)$ at $-78{ }^{\circ} \mathrm{C}($ Table 1 , entries 14, 15).

Weinreb amides are alternative acylating agents to classical ones. ${ }^{29-31}$ On account of that fact, we decided to examine the effectiveness of $N$-methoxy- $N$-methylacetamide (AcN(OMe)Me), $N$-methoxy- $N, 2,2-$ trimethylpropanamide (PivN(OMe)Me) and $N$-methoxy-N,2-dimethylpropanamide ('PrCON(OMe)Me) in the reactions with naphthalene derivatives $\mathbf{1 a}$ or $\mathbf{4 a} .^{32}$ We noticed that bis-lithiated species $\mathbf{1 a}$ reacted with $\mathrm{AcN}(\mathrm{OMe}) \mathrm{Me}$ as well as PivN(OMe)Me at $-20^{\circ} \mathrm{C}$ giving corresponding $\mathbf{2 a}$ and $\mathbf{2} \mathbf{b}$ in merely moderate $30 \%$ yield (Table 1, entries 4, 8). Surprisingly, the effectiveness of Weinreb amides ( $\mathrm{AcN}(\mathrm{OMe}) \mathrm{Me}$, ${ }^{\mathrm{P}} \operatorname{COON}(\mathrm{OMe}) \mathrm{Me}$ ) in the acylation of $\mathbf{4 a}$ was very low and the desired products $\mathbf{5 a , b}$ were formed in trace amounts (Table $\mathbf{1}$, entries $\mathbf{1 3}$, 16). Besides products $\mathbf{2}$ or $\mathbf{5}$ and mentioned above $\mathrm{N}$-acetyl carbamate $\mathbf{3}$ (as an effect of the reaction of $\mathbf{1 a}$ with $\mathrm{Ac}_{2} \mathrm{O}$, Table 1, entry 3), from the post reaction mixture some amounts of starting carbamates 1 or 4 (10-50\%), ketoamide 6 (8\%), N-Boc 2-naphthylamine 7 (5-60\%) and naphtho[2,1-d][1,3]oxazin-3-one 8 (5-10\%) were also isolated (confirmed by ${ }^{1} \mathrm{H},{ }^{13} \mathrm{C}$ NMR, HRMS, Table 1, entries 11, 13-15). The formation of ketoamide 6, appears to result from the $C$-acylation of lithiated $N$-(naphthalen-2-yl)acetamide 9 by $A_{2} \mathrm{O}$, followed by quenching with methanol. The generation of $\mathbf{9}$ was most probably due to the ability of $\mathrm{N}$-Boc-2-naphthylamine derivatives to cleave the Boc protecting group under basic conditions accompanied by $N$-acylation with $\mathrm{Ac}_{2} \mathrm{O}$ (Scheme 2 ). ${ }^{27}$
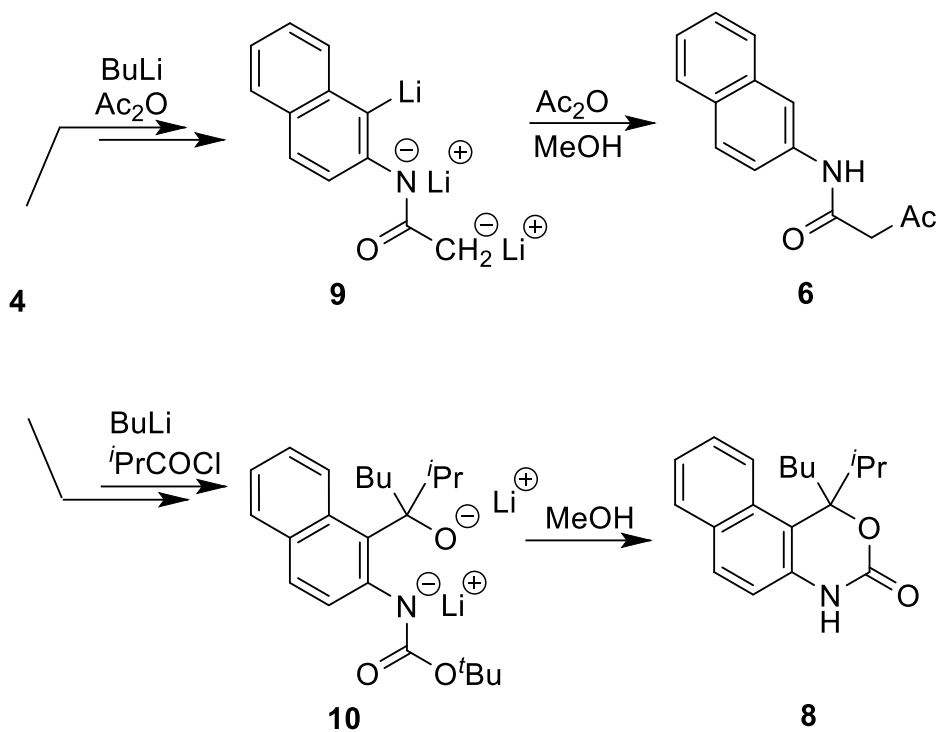

Scheme 2. Possible pathways for the formation of 6 and 8.

This type of acetamide aldolization for the first time has been reported by Hauser and Gay. ${ }^{33}$ They observed that acetanilide can be efficiently deprotonated by BuLi to produce the corresponding dianion, which is able to react with diverse electrophiles. ${ }^{34}$ In turn, the formation of 8 seems to result from BuLi addition (excess of BuLi) to the carbonyl group of the emerging keto derivative which subsequently transforms into adduct $\mathbf{1 0}$ and finally to $\mathbf{8}$ via an the intramolecular cyclization (Scheme 2). 
We have observed the formation of systems similar to 8 in the reaction of the bis-lithium derivative generated from N-Boc-2-naphthylamine 7 ( ${ }^{\mathrm{B}} \mathrm{BuLi} / \mathrm{TMEDA}$ ) and acetaldehyde (Scheme 3 ). The ${ }^{1} \mathrm{H}$ NMR spectrum of the post reaction complex mixture indicated signals belonging to methyl-1,4-dihydronaphto-1,3-oxazinones 13 and 14 (the ratio ca. 3:5, ${ }^{1} \mathrm{H}$ NMR) Ultimately, from the crude material only compound 14 was isolated in the pure form ( $40 \%$ yield).

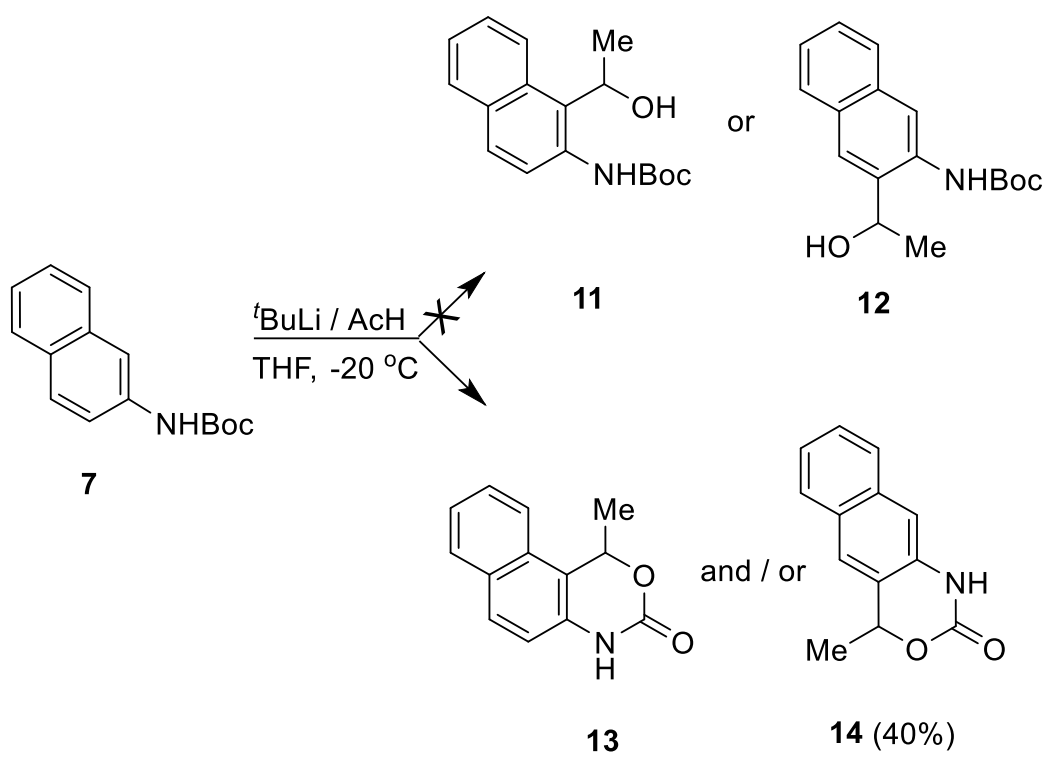

Schemat 3. Reaction of $N$-Boc-2-naphthylamine 7 with ${ }^{\text {tB }} \mathrm{BuLi} /$ acetaldehyde.

In the literature several strategies have been described for the construction of a quinazoline skeleton, e.g. using aromatic nitroaldehydes, ${ }^{35}$ imido amides ${ }^{36}$ or amines, ${ }^{37,38}$ as substrates. There are some procedures for the preparation of functionalized benzoquinazolines from naphthylamine derivatives like e.g. amidines (reactions with DMFA) ${ }^{39}$ or anilides (reactions with ammonium formate). ${ }^{38}$ However, there are few examples of the synthesis of benzoquinazoline systems with simple alkyl substituents. ${ }^{38,40,41}$

In this work alkylbenzoquinazoline derivatives were synthesized by the thermal condensation $\left(170{ }^{\circ} \mathrm{C}\right)$ of (acylnaphthyl)carbamates 2a,b, 18 or their derivatives 15a, 19 with $\mathrm{HCONH}_{2} / \mathrm{AcONH}_{4}$ (Scheme 4). Transformation of aminoketones 15a, 19 provided the desired products 16a, 20 in moderate yields (35\%, 30\%, respectively). Much better results were obtained from the direct reaction of $N$-Boc derivatives $\mathbf{2 a}, \mathbf{2 b}$ or $\mathbf{1 8}$ with formamide/AcONH 4 . The corresponding alkylbenzoquinazolines $\mathbf{1 6} \mathbf{a}, \mathbf{b}$ and $\mathbf{2 0}$ were obtained in $50-60 \%$ yields. Attempts to modify the reaction conditions for $\mathrm{N}$-Boc derivatives, e.g. by the replacement of ammonium acetate by formic acid or the use only of formamide, led to a substantial decrease in yield (e.g. 16a, 10-20\% by use of $\mathrm{HCONH}_{2} / \mathrm{HCOOH}$ or $25-35 \%$ via reaction with $\mathrm{HCONH}_{2}$ ).

In our opinion, the formation of quinazolines $\mathbf{1 6} \mathbf{a}, \mathbf{b}$ and $\mathbf{2 0}$ from ketones (2a,b and 18, Scheme 4) by condensation with formamide runs through the formation of arylamidine type intermediate 17a and then the ring closure reaction with a subsequent elimination of water. This can be supported by the fact that the $N$-Boc derivatives $\mathbf{2} \mathbf{a}, \mathbf{b}$ and $\mathbf{1 8}$ during the reaction with formamide, underwent deprotection to their parent ketoamines (isolated yields 6-15\%) in any case. 
<smiles>CC(C)(C)C(=O)c1ccc2ccccc2c1Nc1ccccc1</smiles>

$2 a, b$
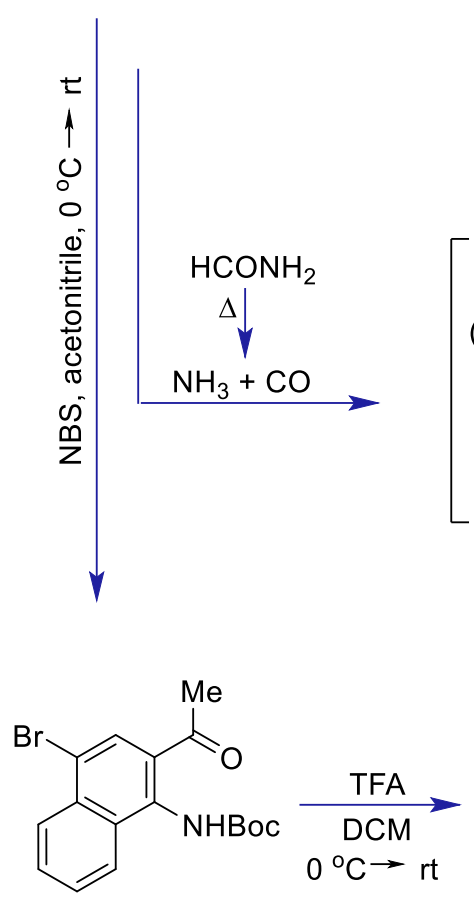

$18(80 \%)$<smiles>CC(=O)c1ccc2ccccc2c1N</smiles>

$15 a(66 \%)$<smiles>Cc1ncnc2c1ccc1ccccc12</smiles>

$16 a$ (35\% from 15a) $(52 \%$ from $2 a)$<smiles>CC(C)(C)c1ncnc2c1ccc1ccccc12</smiles>

$16 \mathrm{~b}$ (60\% from $2 \mathbf{b}$ )

$$
\begin{array}{|l}
\text { (30\% from 19) } \\
\mathrm{HCONH}_{2}, \mathrm{AcONH}_{4}, \Delta
\end{array}
$$

Scheme 4. Synthesis of benzoquinazolines 16, 20 from acyl derivatives of N-Boc-1-naphthylamine 2.

Next, we employed naphthalene ketone $\mathbf{1 9}$ in the synthesis of formamido quinazoline $\mathbf{2 1}$ via the one-pot type reaction comprising 1) condensation of amine 19 with $\mathrm{HCONH}_{2}$ and 2) cross coupling reaction with excess of formamide in the presence of $\mathrm{PdCl}_{2}\left(\mathrm{PPh}_{3}\right)_{2}(30 \mathrm{~mol} \%$ ). Nonetheless, this way of synthesis did not give the expected product 21 (Scheme 5). The ${ }^{1} \mathrm{H}$ NMR (DMSO- $d_{6}$ ) spectrum of isolated compound did not show signals belonging to protons of the $-\mathrm{NHCHO}$ group at position 6 of benzoquinazoline skeleton. The obtained spectrum was identical to the one observed for compound 16a. Thereby, in the course of this reaction the 6 -hydride elimination dominated in the last stage of the catalytic cycle and in consequence led to the formation of $16 a$ (50\%) instead 21. Finally, the target product 21 was obtained by the $\mathrm{Cu}(\mathrm{II})$ mediated coupling reaction ${ }^{42}$ of quinazoline $\mathbf{2 0}$ with an excess of formamide with access to air (52\%, Scheme 5). The spectroscopic analysis indicated that $N$-arylformamide derivative $\mathbf{2 1}$ existed as a mixture of two rotamers $(\approx 2: 1)$, favoring the $Z$ form. 

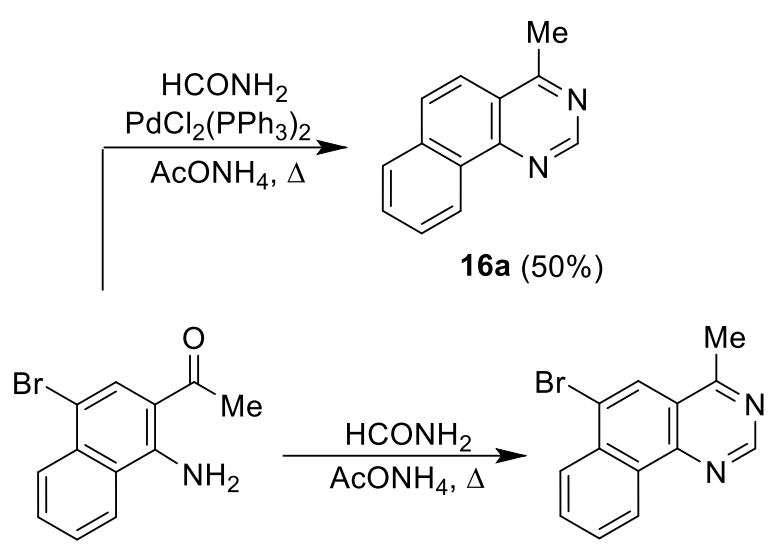

19 $20(45 \%)$

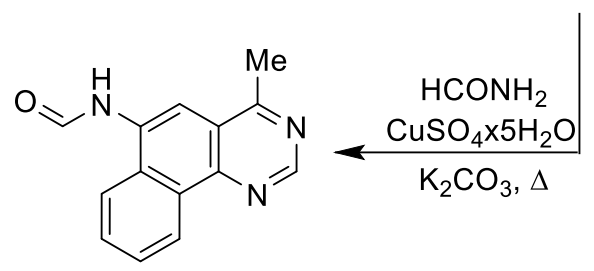

$21(52 \%)$

Scheme 5. The formamidation reaction of benzoquinazoline derivatives 19, 20.

The second part of the presented work concerned the investigation of the behavior of acyl derivatives 2 or/and $\mathbf{5}$ in the synthesis of benzo[f]quinazolin-3(4H)-ones $\mathbf{2 2}$ and benzo[h]quinazolin-2(1H)-ones $\mathbf{2 3}$ (Scheme 6). Heterocycles containing a quinazolin-2(1H)-one scaffold are a relatively little-studied class. Some studies reported that quinazolin-2(1H)-ones can be obtained by cyclization reactions using amino acetophenones $25,43,44$ or aminobenzonitriles. ${ }^{45}$ Our studies on the construction of benzoquinazolinone systems using $\mathrm{N}$-Boc 2 naphthylamine derivatives showed that, when a solution of $\mathbf{5 a}$ in acetic acid was treated with a large excess of potassium cyanate, the methylbenzoquinazolinone (22a) can be produced in a satisfactory yield (50\%, Scheme 6). In addition, when ammonium acetate was added to the reaction mixture, the yield of lactam $22 \mathrm{a}$ increased up to $65 \%$. In accordance with this methodology, when the isopropyl derivative $\mathbf{5 b}$ was treated with a mixture of $\mathrm{KOCN}, \mathrm{AcONH}_{4}$ the desired product $22 \mathrm{~b}$ was obtained in $40 \%$ yield (Scheme 6 ).

The transformation of $\mathrm{N}$-Boc 1-naphthylamine derivatives $\mathbf{2 a}$ and $\mathbf{2 b}$ into lactams $\mathbf{2 3 a}$ (23\%) and 23b (15\%) was less efficient. ${ }^{1} \mathrm{H}$ NMR spectra of post reaction mixtures, showed that the main ingredients were the starting carbamates $\mathbf{2}$. Furthermore, proton signals for the aminoketone generated by Boc group cleavage from $\mathbf{2 b}$ were also observed. The analysis of obtained results gives a ground for conclusion that the conversion of acyl carbamates $\mathbf{2}$ or $\mathbf{5}$ into corresponding benzoquinazolinones 22, $\mathbf{2 3}$ runs through the acidic deprotection of the amino group, as the first step and then condensation of the resulting ketoamine with potassium cyanate giving finally benzoquinazolinones (see supplementary material, Scheme S1, Path A: $\mathbf{I} \rightarrow \mathbf{V} \rightarrow \mathbf{V I} \rightarrow \mathbf{V I I} \rightarrow \mathbf{I I}$ ). On the other hand, the presence of $\mathrm{AcONH}_{4}$, which can act as a source of nitrogen (ammonium) implies the possibility to include the alternative pathway by the formation of an imidoyl derivative VIII (see supplementary material, Scheme S1, Path B: $\mathbf{I} \rightarrow \mathbf{V I I I} \rightarrow \mathbf{I X} \rightarrow \mathbf{I I}$ ). 


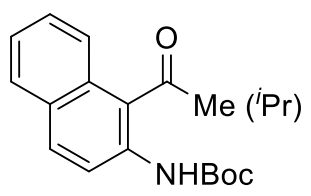

$5 a, b$

1) $\mathrm{AcOH}\left(80 \%_{a q}\right), \Delta$

2) $\mathrm{KOCN}, \mathrm{H}_{2} \mathrm{O}$ $\mathrm{AcONH}_{4}, \Delta$
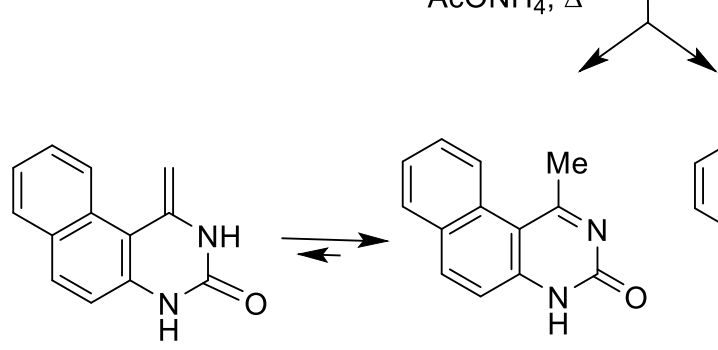

24

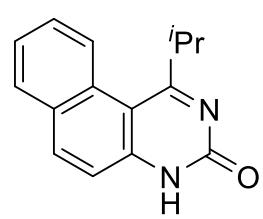

22b $(40 \%)^{a)}$<smiles>CC(=O)OCc1c(C(C)(C)C)ccc2ccccc12</smiles>

$2 a, b$
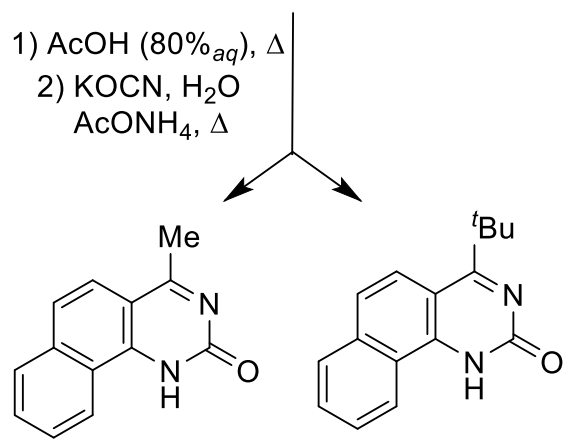

$23 a(15 \%)^{b)}$

23b $(23 \%)^{b)}$

Scheme 6. The synthesis of alkyl 4-alkylbenzo[ $h$ ]quinazolin-2(1H)-ones 22 and 1-alkylbenzo [f]quinazolin$3(4 H)$-ones 23; a) isolated yield; b) ${ }^{1}$ H NMR yield.

In the case of quinazolinones the lactam-lactim tautomerism is possible, wherein amide is the major form. Additionally, in quinazolinone systems containing a methyl group at position 4 or 2 , the tautomerism effect can extend to include the methylidene form. The spectroscopic analysis $\left({ }^{1} \mathrm{H},{ }^{13} \mathrm{C} N \mathrm{NR}\right)$ of compounds $22 \mathrm{a}, \mathbf{b}$ showed that methylquinazolinone $22 \mathrm{a}$ in DMSO- $d_{6}$ solution exist in equilibrium with its tautomeric form $\mathbf{2 4}$ (Scheme 6) (see supplementary material, Fig. S1). The series of spectra recorded within 7 days demonstrated that the concentration of the methylidene form $\mathbf{2 4}$ increase till to $\approx 14 \%$. Compound $\mathbf{2 2 b}$ remained in this form. Crucial for the identification of tautomers $\mathbf{2 2 a}$ and $\mathbf{2 4}$ were the ${ }^{1} \mathrm{H}$ NMR signals of the NH protons observed as a broad singlet at $12.11 \mathrm{ppm}$ for the lactam form 22a (at $12.06 \mathrm{ppm}$ for $\mathbf{2 2} \mathbf{b}$ ) and as two singlets at 9.94 and $9.48 \mathrm{ppm}$ for methylidene derivative 24. Also, methylidene proton signals $\left(\mathrm{C}=\mathrm{CH}_{2}\right)$ of $\mathbf{2 4}$ observed as two singlets at 4.86 and $4.74 \mathrm{ppm}$ as well as a singlet of methyl protons of 22a at $3.04 \mathrm{ppm}$, had the essential diagnostic value. By contrast, in the interpretation of ${ }^{13} \mathrm{C}$ NMR spectrum of a mixture of $2 \mathbf{2 a} \leftrightarrows 24$ the significant role is played by the resonance signals for $C=\mathrm{N}$ and $C=\mathrm{O}$ carbon atoms of $22 \mathrm{a}$ located at 174.0 and $154.1 \mathrm{ppm}$, respectively (lit. $\approx$ $177-180.5 \mathrm{ppm}(C=\mathrm{N}), \approx 158 \mathrm{ppm}(C=0))^{46,47,48}$ and the carbon atom signal of an alkyl group at $30.0 \mathrm{ppm}$ (lit. $\approx$ $22.9 \mathrm{ppm}) .{ }^{46,47,48} \mathrm{~A}$ similar image was observed in the ${ }^{13} \mathrm{C}$ NMR spectrum of compound $\mathbf{2 2} \mathbf{b}$. The corresponding carbon atom signals of $C=\mathrm{N}$ and $C=\mathrm{O}$ moiety were located at 181.7 and $154.4 \mathrm{ppm}$, respectively. For the identification of compound type $\mathbf{2 4}$, useful were also signals of the methylidene carbon $\left(\mathrm{C}=\mathrm{CH}_{2}\right)$ situated at 91.7 ppm (lit. $\approx 84-88 \mathrm{ppm}$ ) and $\mathrm{C}=\mathrm{CH}_{2}, \mathrm{C}=\mathrm{O}$ at 138.5 and $151.1 \mathrm{ppm}$ (lit. $\approx 150-159 \mathrm{ppm}$ ), respectively. ${ }^{46,47,48}$ The comparison of ${ }^{13} \mathrm{C}$ NMR spectroscopic data for both quinazolinones 22a and 22b with carbon chemical shifts was calculated using GIAO method at the B3LYP/6-311++G(d,p) level of theory in DMSO- $d_{6}$ solution (IEF-PCM implicit solvation model) and allowed to signals identify and next their assignment to the corresponding carbon atoms (see supplementary material, Table S1). The calculated ${ }^{13} \mathrm{C} N M R$ shifts of atoms C4a-C10b of the naphthalene system 22 b, as was shown in Table S1 (entries 4, 7, 10-12, 14, 17, 18, 21, 23) were located in the range 117.7-151.6 ppm and they have been assigned to ten experimental signals observed in NMR spectrum at 
$144.8,136.8,129.9,129.8,128.8,128.4,125.1,124.8,116.3$ and 109.4 ppm. In the case of 22a chemical shifts of carbon atoms $\mathrm{C} 4 \mathrm{a}-\mathrm{C} 10 \mathrm{~b}$ indicated similar values. Slightly greater differences were visible for $C=\mathrm{N}(\mathrm{C} 1)$ and $C=\mathrm{O}$ (C3) carbons. The comparison between theoretical and experimental ${ }^{13} \mathrm{C}$ NMR shifts for $\mathrm{C} 1$ and $\mathrm{C} 3$ carbon atoms were as follows: signals of $\mathbf{2 2 b}$ were found at 193.5 and $181.7 \mathrm{ppm}$ for $C=\mathrm{N}$, and at 161.1 and $154.4 \mathrm{ppm}$ for $C=0$, while for 22a at 185.8 and 174.0 ppm, and at 160.4 and 154.1 ppm, respectively. The calculated ${ }^{13} \mathrm{C}$ NMR shift values correlated well with their experimental counterparts with the correlation coefficient $\left(r^{2}\right)$ of 0.9992 (22a), 0.9996 (22b) and 0.9913 (24).

In our previous work we demonstrated that a morpholine substituent attached to the benzo[ $h]$ quinazolinone scaffold can be responsible for increased cytotoxicity properties. In the last part of this work 3-substituted-6-bromobenzo[h]quinazolin-4(3H)ones $\mathbf{2 6 a}, \mathbf{b}^{26,27}$ were subjected to the $\mathrm{Cu}(\mathrm{II})$ catalyzed formamidation ${ }^{42}$ and $\mathrm{Pd}_{2}(\mathrm{dba})_{3} /$ Binap/ $\mathrm{Cs}_{2} \mathrm{CO}_{3}$ catalyzed Buchwald-Hartwig amination reaction (Scheme 7). According this, target formamides $\mathbf{2 7 a} \mathbf{a} \mathbf{b}$ were obtained in $60 \%$ and $40 \%$ yield, respectively, in turn the morpholine products $\mathbf{2 8 a}$, b were isolated in $55 \%$ and $68 \%$ yields. ${ }^{1} \mathrm{H}$ NMR spectra of the new formamides 27 possess a double set of resonance signals, which points out that compounds $27 \mathbf{a}$ and $27 \mathbf{b}$, similarly as 21 exist in two rotameric forms in DMSO- $d_{6}$ solution, and the cis form is dominant (cis:trans $\approx 3: 1$ ).<smiles>O=CNc1cc2c(=O)n(Cc3ccccc3)cnc2c2ccccc12</smiles>

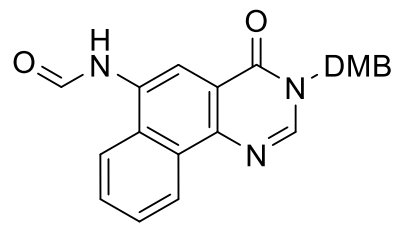<smiles>[124CH3]</smiles>

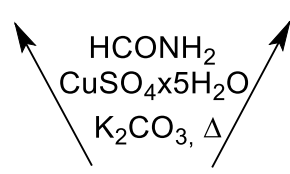

$27 b(40 \%)$<smiles>CCOC(=O)c1ccc2ccccc2c1NC(C)=CC(C)(C)C(C)(C)C</smiles>

26a,b

$25^{26,27}$

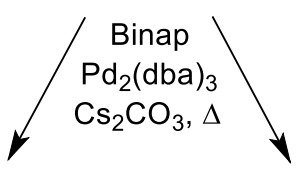<smiles>O=c1c2cc(N3CCOCC3)c3ccccc3c2ncn1Cc1ccccc1</smiles>

$28 \mathrm{a}(55 \%)$<smiles>[R16]On1cnc2c(cc(N3CCOCC3)c3ccccc32)c1=O</smiles>

28b (68\%)

Scheme 7. The formamidation reaction of benzoquinazolinone derivatives 26.

The cytotoxic activity of the tested quinazoline, quinazolinonene derivatives were evaluated against HT29 human colorectal adenocarcinoma cell line using the MTT test and additionally towards the normal human 
lymphocytes. The obtained IC $\mathrm{C}_{50}$ values were collected in Table 2 . In addition, in order to interpret more fully the results obtained, the cytotoxicity values of compounds $\mathbf{3 0 - 3 3}$, evaluated in our earlier papers ${ }^{26,27}$ and also cisplatin ${ }^{49}$ were also added to Table 2.

Table 2. $I C_{50}$ values of compounds $21,27-33$

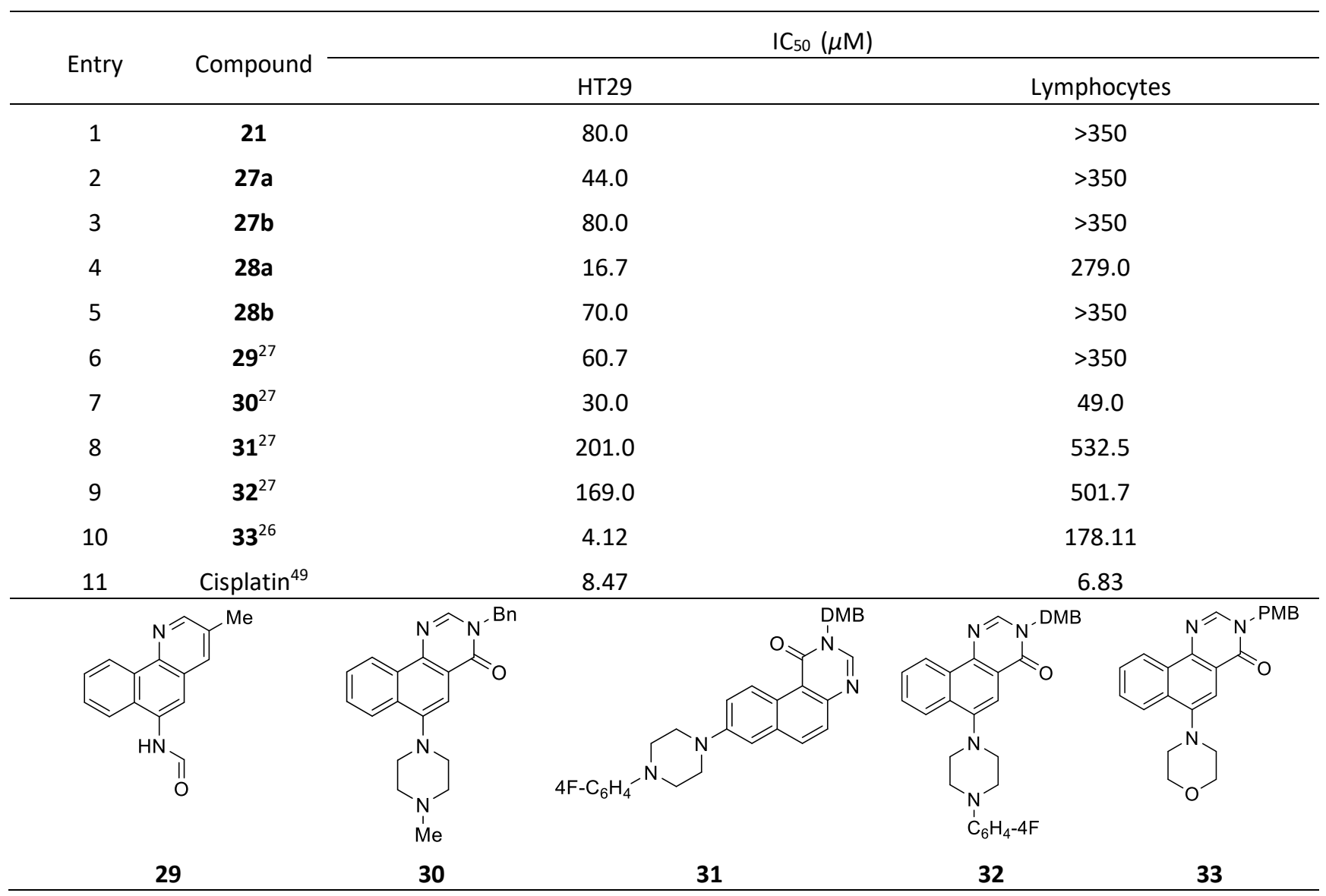

The tested new synthesized derivatives $\mathbf{2 1}, \mathbf{2 7}, \mathbf{2 8}$ showed different activity. Out of these compounds the most interesting results were obtained for morpholine benzoquinazolinone $28 \mathrm{a}$ ( $\mathrm{IC}_{50} 16.7 \mu \mathrm{M}$ ), formamido benzoquinazolinone 27a $\left(\mathrm{IC}_{50} 44.0 \mu \mathrm{M}\right)$ and formamido benzoquinoline $29\left(\mathrm{IC}_{50} 60.7 \mu \mathrm{M}\right)$, which exhibited the highest cytotoxicity against HT29 cell line. As it can be seen from Table 2, N-benzyl-benzoquinazolinone 28 a (IC 50 $16.7 \mu \mathrm{M})$ showed a greater toxicity than $N$-benzyl-benzoquinazolinone $\mathbf{3 0}\left(\mathrm{IC}_{50} 30.0 \mu \mathrm{M}\right)$ and $N$-dimethoxybenzyl derivative 28b (IC $70.0 \mu \mathrm{M})$. Regarding the activity of presented morpholine benzo[h]quinazolinones, compounds 28a, 28b were less active than methoxybenzyl derivative 33 (IC $50.12 \mu \mathrm{M})$. It might be suggested that cytotoxic activity for tested morpholine benzo[ $h$ ]quinazolin-4(3H)-ones was dependent on the substituent at the lactam nitrogen atom and the trend of increasing antitumor activity for these compounds was $\mathrm{PMB}>\mathrm{Bn}>\mathrm{DMB}$. Generally, the introduction of the morpholine moiety into the 3,4-dimethoxybenzyl benzoquinazolinone skeleton in return of the 4-(4-fluorophenyl)piperazin-1-yl (for 32, IC $50169.0 \mu \mathrm{M}$ ) moiety, had an impact on the increase of activity (for $\mathbf{2 8 b}, I_{50} 70.0 \mu \mathrm{M}$ ). However, the fluorophenylpiperazin-1-yl derivative 32 showed greater activity than their benzo[f]- analogue 31 (IC $201.0 \mu \mathrm{M})$. 


\section{Conclusions}

We have presented a method to prepare of acylnaphthalenecarbamates $\mathbf{2} \mathbf{a}, \mathbf{b}, \mathbf{5} \mathbf{a}, \mathbf{b}$ as precursors in the synthesis of alkyl substituted benzo[f]quinazolin-3(4H)-ones $\mathbf{2 2} \mathbf{a} \mathbf{a} \mathbf{b}$, benzo[h]quinazolin-2(1H)-ones $\mathbf{2 3 a}, \mathbf{b}$ and also benzoquinazolines $\mathbf{1 6 a , b}, \mathbf{2 0}$. New benzoquinazolinyl formamides $\mathbf{2 1}$, 28a,b achieved via copper catalyzed coupling reaction can constitute a suitable starting point for further modifications.

\section{Experimental Section}

General. Melting points were determined on a Boetius hot stage apparatus and were uncorrected. ${ }^{1} \mathrm{H},{ }^{13} \mathrm{C} \mathrm{NMR}$ spectra were recorded on a Bruker Advance III spectrometer at $600 \mathrm{MHz}, 150 \mathrm{MHz}$ respectively. The residual $\mathrm{CDCl}_{3}$ or DMSO- $d_{6}$ signal was used for reference $\left(\mathrm{CDCl}_{3}\right.$ at $7.26 \mathrm{ppm}$ or DMSO- $d_{6}$ at $2.54 \mathrm{ppm}$ for ${ }^{1} \mathrm{H}$ NMR and $\mathrm{CDCl}_{3}$ at $77.0 \mathrm{ppm}$ or DMSO- $d_{6}$ at $39.0 \mathrm{ppm}$ for ${ }^{13} \mathrm{C} \mathrm{NMR).} \mathrm{IR} \mathrm{spectra} \mathrm{were} \mathrm{recorded} \mathrm{on} \mathrm{a} \mathrm{Nexus} \mathrm{FT-IR}$ spectrometer. LC/HRMS analyses were performed using an Agilent Technologies HPLC 1290 coupled to an Agilent Technologies 6550 Accurate Mass Q-TOF LC-MS mass spectrometer equipped with a JetStream Technology ion source housed in the Department of Pathophysiology, Medical University of Lublin, Poland. Internal mass calibration was enabled, reference ions of $\mathrm{m} / \mathrm{z} 121.0509$ and 922.0098 were used. The analytical thin layer chromatography tests (TLC) were carried out on Sigma Aldrich (Supelco) silica gel plates (Kiselgel 60 F254, layer thickness $0.2 \mathrm{~mm}$ ) and the spots were visualized using UV lamp. The flash column chromatography purifications were performed on Fluka silica gel (Silica gel 60, 0.040-0.063 mm).

Butyllithium (BuLi) solution in hexanes (Aldrich), tert-butyllithium ( ${ }^{\mathrm{B}} \mathrm{BuLi}$ ) solution in pentane (Aldrich) were each time titrated before use. ${ }^{26}$ All reactions with organolithium and organopalladium compounds were performed under an argon atmosphere using standard Schlenk technique. Diethyl ether, THF and 1,4-dioxane were distilled from sodium benzophenone ketyl prior to use. Commercially available solvents and reagents: acetyl chloride $(\mathrm{AcCl})$, acetic anhydride $\left(\mathrm{Ac}_{2} \mathrm{O}\right)$, ethyl acetate ( $\left.\mathrm{AcOEt}\right)$, pivaloyl chloride ( $\left.\mathrm{PivCl}\right)$, isobutyryl chloride ('PrCOCl), acetaldehyde $(\mathrm{AcH})$, 1-naphthylamine, formamide, $\mathrm{Boc}_{2} \mathrm{O}$, ethyl chloroformate, benzyl bromide $(\mathrm{BnBr}), 3,4$ dimethoxybenzyl bromide (DMBBr), $\mathrm{N}$-bromosuccinimide (NBS), $\mathrm{CuSO}_{4} \times 5 \mathrm{H}_{2} \mathrm{O}$, binap, $\mathrm{Pd}_{2}(\mathrm{dba})_{3}, \mathrm{PPh}_{3} \mathrm{PdCl}_{2} \mathrm{PPh}_{3}$, acetic acid ( $\mathrm{AcOH} 80 \%$ aq.), potassium cyanate (KOCN), ammonium acetate $\left(\mathrm{AcONH}_{4}\right), 1,4$-dioxane, $\mathrm{THF}, \mathrm{Et} \mathrm{H}_{2} \mathrm{O}$, acetonitrile were purchased from Sigma-Aldrich, Flucka or POCh and were used without further purification.

$N$-Boc-1-naphthylamine (2), N-Boc-1-bromo-2-naphthylamine (4), N-Boc-2-naphthylamine (8), $N$-methoxy- $N$ methylacetamid (AcN(OMe)Me), N-methoxy-N,2,2-trimethylpropanamide (PivN(OMe)Me), N-methoxy- $N, 2-$ dimethylpropanamide ('PrCON(OMe)Me), 3-benzyl-6-bromobenzo[h]quinazolin-4(3H)-one (26a), 6-bromo-3[(3,4-dimethoxyphenyl)methyl]benzo[ $h]$ quinazolin-4(3H)-one $\quad$ (26b), $\quad N$-(3-methylbenzo[h]quinolin-6$\mathrm{yl})$ formamide (29) were prepared by a procedure similar to that in the literature. ${ }^{26,27,32}$

General procedure for the preparation of compounds 2,5. Under argon, to a solution of $\mathrm{N}$-Boc-1naphthylamine (1) or N-Boc-1-bromo-2-naphthylamine (4) $(2.1 \mathrm{mmol})$ in dry $\mathrm{Et}_{2} \mathrm{O}(20 \mathrm{~mL})$, at $-20{ }^{\circ} \mathrm{C},{ }^{\mathrm{t}} \mathrm{BuLi}$ solution in pentane or BuLi solution in hexanes ( 2.2 equiv.) was added dropwise. The reaction mixture was stirred at this temperature for 2 hours. After this time, 1 equiv. of electrophile at $-78{ }^{\circ} \mathrm{C}$ ( for $\mathrm{Ac}_{2} \mathrm{O}$ ) or at $-20^{\circ} \mathrm{C}$ (for ${ }^{i} \mathrm{PrCOCl}$ or $\mathrm{PivCl}$ ) was added dropwise and whole was further stirred at appropriate temperature for next 2 hours. Next, to the reaction mixture $20 \mathrm{~mL}$ of methanol was added. Evaporation of solvents and purifications of the crude residue by flash chromatography gave the desired product $\mathbf{2}$ or $\mathbf{5}$. In the case of the reaction of $\mathbf{1}$ with 
$\mathrm{Ac}_{2} \mathrm{O}$ at $-78{ }^{\circ} \mathrm{C}$ from post-reaction mixture also substrate and compound $\mathbf{3}$ were isolated. On the other hand from reaction of 4 with $\mathrm{Ac}_{2} \mathrm{O}$ and ${ }^{~} \mathrm{PrCOCl}$ compounds 6, 7, 8 and a small amount of substrate were isolated.

tert-Butyl (2-acetylnaphthalen-1-yl)carbamate (2a). Light yellow solid, yield $45 \%, 270 \mathrm{mg}, \mathrm{mp} 150-152{ }^{\circ} \mathrm{C} ; \mathrm{R}_{f}$ $\left(\mathrm{Hex} /\right.$ AcOEt 5:1) $=0.22$. FTIR $\left(\mathrm{KBr}, v_{\max }, \mathrm{cm}^{-1}\right) 3257,3055,3003,2979,2928,1709,1689 .{ }^{1} \mathrm{H} \mathrm{NMR}\left(\mathrm{CDCl}_{3}\right): \delta 9.26$ $(1 \mathrm{H}, \mathrm{s}, \mathrm{NH}), 8.07(1 \mathrm{H}, \mathrm{d}, J 8.4 \mathrm{~Hz}, \mathrm{Ar}-\mathrm{H}), 7.82(1 \mathrm{H}, \mathrm{d}, J 8.4 \mathrm{~Hz}, \mathrm{Ar}-\mathrm{H}), 7.78(1 \mathrm{H}, \mathrm{d}, J 8.6 \mathrm{~Hz}, \mathrm{Ar}-\mathrm{H}), 7.70(1 \mathrm{H}, \mathrm{d}, J 8.7$ $\mathrm{Hz}, \mathrm{Ar}-\mathrm{H}), 7.56(2 \mathrm{H}, \mathrm{m}, \mathrm{Ar}-\mathrm{H}), 2.71(3 \mathrm{H}, \mathrm{s}, \mathrm{Me}), 1.52$ (9H, s, Boc-Me). ${ }^{13} \mathrm{C} \mathrm{NMR}\left(\mathrm{CDCl}_{3}\right): \delta 202.0,154.5,136.6$, 136.1, 129.1, 128.6, 127.9, 126.7, 126.7, 126.4, 125.5, 125.1, 81.0, 29.6, 28.4. HRMS (ESI) $\mathrm{m} / \mathrm{z}$ calcd for $\mathrm{C}_{17} \mathrm{H}_{20} \mathrm{NO}_{3}: 286.1438$; found $[\mathrm{M}+\mathrm{H}]^{+}: 286.1441$.

tert-Butyl (1-acetylnaphthalen-2-yl)carbamate (5a). Beige solid, yield 55\%, $243 \mathrm{mg}, \mathrm{mp} 119-121^{\circ} \mathrm{C} ; \mathrm{R}_{f}$

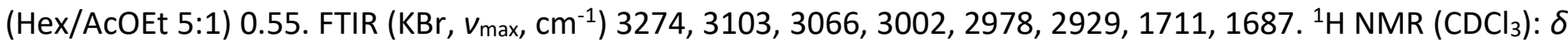
$8.31(1 \mathrm{H}, \mathrm{s}, \mathrm{NH}), 8.26(1 \mathrm{H}, \mathrm{d}, J 9.1 \mathrm{~Hz}, \mathrm{Ar}-\mathrm{H}), 7.87(1 \mathrm{H}, \mathrm{d}, J 9.1 \mathrm{~Hz}, \mathrm{Ar}-\mathrm{H}), 7.82(1 \mathrm{H}, \mathrm{d}, J 8.1 \mathrm{~Hz}, \mathrm{Ar}-\mathrm{H}), 7.76(1 \mathrm{H}, \mathrm{d}$, J $8.5 \mathrm{~Hz}, \mathrm{Ar}-\mathrm{H}), 7.54-7.49(1 \mathrm{H}, \mathrm{m}, \mathrm{Ar}-\mathrm{H}), 7.46-7.41(1 \mathrm{H}, \mathrm{m}, \mathrm{Ar}-\mathrm{H}), 2.69(3 \mathrm{H}, \mathrm{s}, \mathrm{Me}), 1.53(9 \mathrm{H}, \mathrm{s}, \mathrm{Boc}-\mathrm{Me}) .{ }^{13} \mathrm{C}$ $\operatorname{NMR}\left(\mathrm{CDCl}_{3}\right): \delta 206.0,153.2,134.7,132.0,130.3,130.2,128.8,127.4,125.1,124.7,120.8,81.2,33.0$, 28.5. HRMS (ESI) $\mathrm{m} / \mathrm{z}$ calcd for $\mathrm{C}_{17} \mathrm{H}_{20} \mathrm{NO}_{3}$ : 286.1438; found $[\mathrm{M}+\mathrm{H}]^{+}: 286.1435$.

4-Methyl-1,4-dihydro-2H-naphtho[2,3-d][1,3]oxazin-2-one (14). Under argon, to a solution of $\mathrm{N}$-Boc-2naphthylamine (8) $(4.11 \mathrm{mmol})$ in dry THF $(20 \mathrm{~mL})$, at $-20{ }^{\circ} \mathrm{C}$, TMEDA (2.2 equiv.) and next ${ }^{\mathrm{t}}$ BuLi solution in pentane ( 2.2 equiv.) was added dropwise. The reaction mixture was stirred at this temperature for 2 hours. After this time, at $-20^{\circ} \mathrm{C}, 6.5$ equiv. of acetaldehyde was added dropwise and whole was further stirred at -20 ${ }^{\circ} \mathrm{C}$ for next 1 hour. Next, to the reaction mixture $20 \mathrm{~mL}$ of methanol was added. Evaporation of solvents and purification of the crude residue by flash chromatography gave 14. White solid, yield $40 \%, 350 \mathrm{mg}, \mathrm{mp} 204-206$ ${ }^{\circ} \mathrm{C} ; \mathrm{R}_{f}\left(\mathrm{Hex} /\right.$ AcOEt 4:3) $=0.34$. FTIR $\left(\mathrm{KBr}, v_{\max }, \mathrm{cm}^{-1}\right) 3432,1713,1296 .{ }^{1} \mathrm{H} \mathrm{NMR}\left(\mathrm{CDCl}_{3}\right): \delta 9.54(1 \mathrm{H}, \mathrm{s}, \mathrm{NH}), 7.77$ $(1 \mathrm{H}, \mathrm{dd}, J$ 8.1, $0.4 \mathrm{~Hz}, \mathrm{Ar}-\mathrm{H}), 7.73(1 \mathrm{H}, \mathrm{dd}, J$ 8.1, $0.4 \mathrm{~Hz}, \mathrm{Ar}-\mathrm{H}), 7.57(1 \mathrm{H}, \mathrm{s}, \mathrm{Ar}-\mathrm{H}), 7.46(1 \mathrm{H}, \mathrm{ddd}, J$ 8.1, 6.9, $1.2 \mathrm{~Hz}$, Ar-H), $7.39(1 \mathrm{H}, \mathrm{ddd}, J$ 8.1, 6.8, 1.2 Hz, Ar-H), $7.28(1 \mathrm{H}, \mathrm{s}, \mathrm{Ar}-\mathrm{H}), 5.67(1 \mathrm{H}, \mathrm{qd}, J$ 6.6, $1.2 \mathrm{~Hz}, \mathrm{CH}), 1.84(3 \mathrm{H}, \mathrm{d}, J 6.6$ $\mathrm{Hz}, \mathrm{Me}) .{ }^{13} \mathrm{CNMR}\left(\mathrm{CDCl}_{3}\right): \delta 154.1,133.9,133.1,130.3,128.1,127.2,127.0125 .1,124.0,123.3,110.3,75.9,20.4$. HRMS (ESI) $m / z$ calcd for $\mathrm{C}_{13} \mathrm{H}_{12} \mathrm{NO}_{2}: 214.0863$; found $[\mathrm{M}+\mathrm{H}]^{+}: 214,0866$.

Bromo carbamate 18 .To a solution of the appropriate carbamate $2 \mathbf{a}(0.86 \mathrm{mmol})$ in acetonitrile $(10 \mathrm{~mL})$ at $0{ }^{\circ} \mathrm{C}$, a solution of NBS $(1.3 \mathrm{mmol})$ in acetonitrile $(10 \mathrm{~mL})$ was added dropwise. Next, the resulting mixture was allowed to warm to ambient temperature. The reaction was continued under these conditions until TLC analysis of the reaction mixture indicated the absence of starting material 2a ( $\approx$ 3-6 hours). After the reaction was completed, acetonitrile was removed under reduced pressure and the bromo derivative 18 was separated by flash chromatography. Beige solid, yield 80\%, $251 \mathrm{mg}, \mathrm{mp} 161-163{ }^{\circ} \mathrm{C} ; \mathrm{R}_{f}(\mathrm{Hex} / \mathrm{AcOEt} 10: 1)=0.20 . \mathrm{FTIR}\left(\mathrm{KBr}, \mathrm{V}_{\max }, \mathrm{cm}^{-}\right.$ 1) 3279, 3002, 2964, 2924, 2854, 1723, 1681. ${ }^{1} \mathrm{H} N M R\left(\mathrm{CDCl}_{3}\right): \delta 9.09(1 \mathrm{H}, \mathrm{s}, \mathrm{NH}), 8.22(1 \mathrm{H}, \mathrm{d}, J 8.4 \mathrm{~Hz}, \mathrm{Ar}-\mathrm{H})$, 8.11-8.05 (2H, m, Ar-H), 7.72-7.66 (1H, m, Ar-H), 7.63-7.56 (1H, m, Ar-H), 2.70 (3H, s, Me), 1.51 (9H, s, Boc$\mathrm{Me}) .{ }^{13} \mathrm{C} \mathrm{NMR}\left(\mathrm{CDCl}_{3}\right): \delta 200.7,154.3,136.3,134.4,130.3,130.0,128.9,127.4,127.2,127.1,122.7,119.6,81.4$, 29.5, 28.4. HRMS (ESI) $\mathrm{m} / z$ calcd for $\mathrm{C}_{17} \mathrm{H}_{19} \mathrm{BrNO}_{3}$ : 364.0543; found [M+H] $]^{+}: 364.0541$.

Procedure for the preparation of aminoketone 15a. To a mixture of $\mathrm{HCl}_{a q}(0.5 \mathrm{M})$ and 1,4-dioxane in the ratio $2: 3(\mathrm{v} / \mathrm{v})$, at room temperature ketone $2 \mathrm{a}(0.48 \mathrm{mmol})$ was added. The resulting mixture was then heated at $50-$ $60{ }^{\circ} \mathrm{C}$ (oil bath) for about 3-4 hours, until TLC analysis of the reaction mixture indicated the absence of starting material $\mathbf{2 a}$. After the reaction was completed, all the volatile materials were removed under reduced pressure and water $(5-10 \mathrm{~mL})$ was added to residue. The mixture was adjusted to $\mathrm{pH}$ 8-10 with saturated $\mathrm{NaHCO}_{3}$ and then extracted with chloroform $(3 \times 20 \mathrm{~mL})$. The combined extracts were dried over $\mathrm{MgSO}_{4}$, concentrated under reduced pressure. A crude residue was subjected to column chromatography to give amine 15 a. 
Procedure for the preparation of amino ketone 19. To the solution of $N$-Boc-amino keton $18(0.88 \mathrm{mmol}) \mathrm{in}$ $\mathrm{DCM}(4.8 \mathrm{~mL})$ at $0^{\circ} \mathrm{C}$, TFA $(8.8 \mathrm{mmol}, 0.67 \mathrm{~mL})$ was added. The resulting mixture was allowed to warm to ambient temperature and stirring in these conditions until the completion of reaction (TLC analysis). After this time, all the volatile materials were removed under reduced pressure and to residue water $(5 \mathrm{~mL})$ was added. The whole lot was adjusted to $\mathrm{pH}=8-10$ (saturated solution of $\left.\mathrm{NaHCO}_{3}\right)$ and next extracted with $\mathrm{DCM}(3 \times 20 \mathrm{~mL})$. The combined extracts were dried over $\mathrm{MgSO}_{4}$ and concentrated under reduce pressure. The crude residue was purified via flash chromatography to give the appropriate amine 19. Yellow solid, yield 85\%, $198 \mathrm{mg}, \mathrm{mp}$ 134-136 ${ }^{\circ} \mathrm{C} ; \mathrm{R}_{f}\left(\mathrm{Hex} /\right.$ AcOEt 5:1) = 0.32. FTIR $\left(\mathrm{KBr}, v_{\max }, \mathrm{cm}^{-1}\right)$ 3439, 3288, 3027, 3000, 1634, 1602. ${ }^{1} \mathrm{H} \mathrm{NMR}\left(\mathrm{CDCl}_{3}\right)$ : $\delta 8.15(1 \mathrm{H}, \mathrm{d}, J 8.4 \mathrm{~Hz}, \mathrm{Ar}-\mathrm{H}), 7.97(1 \mathrm{H}, \mathrm{s}, \mathrm{Ar}-\mathrm{H}), 7.91(1 \mathrm{H}, \mathrm{d}, J 8.4 \mathrm{~Hz}, \mathrm{Ar}-\mathrm{H}), 7.72-7.48\left(4 \mathrm{H}, \mathrm{m}, \mathrm{NH}_{2}, \mathrm{Ar}-\mathrm{H}\right), 2.64$ (3H, s, Me). ${ }^{13} \mathrm{C} \mathrm{NMR}\left(\mathrm{CDCl}_{3}\right): \delta=199.4,148.8,134.5,131.0,130.2,128.1,126.3,124.7,122.2,112.5,107.7,28.5$. HRMS (ESI) $\mathrm{m} / \mathrm{z}$ calcd for $\mathrm{C}_{12} \mathrm{H}_{11} \mathrm{BrNO}$ : 264.0019; found $[\mathrm{M}+\mathrm{H}]^{+}: 264.0016$.

\section{Synthesis of benzoquinazolines 16, 20}

Method A (from amino ketones) and Method B (from carbamates). To a mixture of amino ketone (Method $A$ ) $\mathbf{1 5 a}$ or $19(0.31 \mathrm{mmol})$ or carbamate $\left(\right.$ Method B) $\mathbf{2 a}$ or $\mathbf{2 b}$ or $\mathbf{1 8}(0.31 \mathrm{mmol})$ in $10 \mathrm{~mL}$ of formamide, $\mathrm{MeCOONH}_{4}$ $(0.52 \mathrm{mmol})$ was added. The whole mixture was stirred and heated at $170{ }^{\circ} \mathrm{C}$ (oil bath). After completion of the reaction, as indicated by TLC (7-15 hours), the resulting solution was cooled to room temperature and $40 \mathrm{~mL}$ of water was added. Then mixture was extracted with chloroform (3x10 mL). The organic layer was dried over $\mathrm{MgSO}_{4}$ and concentrated under reduced pressure. A crude residues was purified by column chromatography to afford products 16a, 16b, 20.

Method $\mathbf{C}$ ( $\beta$-hydrogen elimination). To a mixture of amino ketone $19(0.38 \mathrm{mmol})$ in $10 \mathrm{~mL}$ of formamide, $\mathrm{MeCOONH}_{4}(0.66 \mathrm{mmol}), \mathrm{PPh}_{3} \mathrm{PdCl}_{2} \mathrm{PPh}_{3}(0.11 \mathrm{mmol})$ was added. The whole mixture was stirred and heated at $160{ }^{\circ} \mathrm{C}$ (oil bath) with $3 \AA \AA$ molecular sieves. After completion of the reaction, as indicated by TLC ( 25 hours), the resulting solution was cooled to room temperature and $40 \mathrm{~mL}$ of water was added. Then mixture was extracted with chloroform ( $3 \times 10 \mathrm{~mL}$ ). The organic layer was dried over $\mathrm{MgSO}_{4}$ and concentrated under reduced pressure. A crude residue was purified by column chromatography to afford product 16a. Light yellow solid, yield: $35 \%$ (Method A), $21 \mathrm{mg}, 52 \%$ (Method B), $31 \mathrm{mg}, 55 \%$ (Method C), $41 \mathrm{mg}, \mathrm{mp} 136-138{ }^{\circ} \mathrm{C} ; \mathrm{R}_{f}(\mathrm{DCM} / \mathrm{AcOEt} 10: 1)=$ 0.16. FTIR $\left(\mathrm{KBr}, v_{\max }, \mathrm{cm}^{-1}\right)$ 3070, 3042, 2925, 2854, 1621. ${ }^{1} \mathrm{H} N M R\left(\mathrm{CDCl}_{3}\right): \delta 9.32(1 \mathrm{H}, \mathrm{s}, \mathrm{Ar}-\mathrm{H}), 9.30-9.26(1 \mathrm{H}$, $\mathrm{m}, \mathrm{Ar}-\mathrm{H}), 7.95-7.87(3 \mathrm{H}, \mathrm{m}, \mathrm{Ar}-\mathrm{H}), 7.82-7.75(2 \mathrm{H}, \mathrm{m}, \mathrm{Ar}-\mathrm{H}), 2.99(3 \mathrm{H}, \mathrm{s}, \mathrm{Me}) .{ }^{13} \mathrm{C} \mathrm{NMR}\left(\mathrm{CDCl}_{3}\right): \delta 166.5,154.8$, $149.9,135.2,130.6,130.1,128.7,128.0,127.8,125.2,122.3,121.1,22.1$. HRMS (ESI) $\mathrm{m} / z$ calcd for $\mathrm{C}_{13} \mathrm{H}_{11} \mathrm{BN}_{2}$ : 195.0917; found $[\mathrm{M}+\mathrm{H}]^{+}: 195.0914$.

Synthesis of benzoquinazolinones $\mathbf{2 2}, \mathbf{2 3}$. A solution of the appropriate carbamate $\mathbf{2 a}$ or $\mathbf{2 b}$ or $\mathbf{5 a}$ or $\mathbf{5 b}(0.52$ $\mathrm{mmol}$ ) in $5 \mathrm{~mL}$ of $80 \%$ acetic acid was stirred at $130{ }^{\circ} \mathrm{C}$ (oil bath) for 2 hours. Then KOCN (4.44 mmol) and $\mathrm{MeCOONH}_{4}(9.86 \mathrm{mmol})$ in water $(1-2 \mathrm{~mL})$ was added to the mixture. After 30 min. next portion of $\mathrm{KOCN}$ (8.86 $\mathrm{mmol})$ and $\mathrm{MeCOONH}_{4}(9.86 \mathrm{mmol})$ in water $(1-2 \mathrm{~mL})$ was added. The resulting mixture was further heated at $130{ }^{\circ} \mathrm{C}$ (oil bath) for 2.5 hours. After that to the stirring mixture the last portion of KOCN (2.7 mmol) and $\mathrm{MeCOONH}_{4}(9.1 \mathrm{mmol})$ in water $(1-2 \mathrm{~mL})$ was added. The reaction mixture was held at this conditions for next 3 hours. After cooling, $40 \mathrm{~mL}$ water was added. The precipitated solid was filtered and purified by flash chromatography.

1-Methylbenzo[f]quinazolin-3(4H)-one (22a). Gray solid, yield 65\%, $72 \mathrm{mg}, \mathrm{mp}$ decomposition above $280{ }^{\circ} \mathrm{C} ; \mathrm{R}_{f}$ (acetone/MeOH/Hex 2:1:1) = 0.76. ${ }^{1} \mathrm{HNMR}\left(\mathrm{DMSO}-\mathrm{d}_{6}\right): \delta 12.11(1 \mathrm{H}, \mathrm{s}, \mathrm{NH}), 8.60(1 \mathrm{H}, \mathrm{d}, J 8.7 \mathrm{~Hz}, \mathrm{Ar}-\mathrm{H}), 8.21(1 \mathrm{H}$, d, J $8.9 \mathrm{~Hz}, \mathrm{Ar}-\mathrm{H}), 8.01(1 \mathrm{H}, \mathrm{d}, J 7.9 \mathrm{~Hz}, \mathrm{Ar}-\mathrm{H}), 7.78-7.71(1 \mathrm{H}, \mathrm{m}, \mathrm{Ar}-\mathrm{H}), 7.62-7.55(1 \mathrm{H}, \mathrm{m}, \mathrm{Ar}-\mathrm{H}), 7.43(1 \mathrm{H}, \mathrm{d}, J 8.9$ $\mathrm{Hz}, \mathrm{Ar}-\mathrm{H}), 3.04(3 \mathrm{H}, \mathrm{s}, \mathrm{Me})$. HRMS (ESI) $\mathrm{m} / \mathrm{z}$ calcd for $\mathrm{C}_{13} \mathrm{H}_{11} \mathrm{~N}_{2} \mathrm{O}: 211.0866$; found [M+H] ${ }^{+}: 211.0870$. 
Mixture of 1-methylbenzo[f]quinazolin-3(4H)-one (22a) and 1-methylidene-1,4-dihydrobenzo[f]quinazolin3(2H)-one (24) in ratio 1:0.16*. FTIR ( $\left.\mathrm{KBr}, V_{\max }, \mathrm{cm}^{-1}\right)$ 3437, 3003, 2973, 2858, 2822, 2753, 1663, 1621. ${ }^{1} \mathrm{H} \mathrm{NMR}$ (DMSO-d $\left.)_{6}\right): \delta 12.11\left(1 \mathrm{H}\right.$, br s, NH), $9.94\left(1 \mathrm{H}, \mathrm{s}, \mathrm{NH}^{*}\right), 9.58\left(1 \mathrm{H}, \mathrm{s}, \mathrm{NH}^{*}\right), 8.60(1 \mathrm{H}, \mathrm{d}, J 8.7 \mathrm{~Hz}, \mathrm{Ar}-\mathrm{H}), 8.44(1 \mathrm{H}, \mathrm{d}, J$ $\left.8.6 \mathrm{~Hz}, \mathrm{Ar}-\mathrm{H}^{*}\right), 8.21(1 \mathrm{H}, \mathrm{d}, J 8.9 \mathrm{~Hz}, \mathrm{Ar}-\mathrm{H}), 8.01(1 \mathrm{H}, \mathrm{dd}, J \mathrm{~J} .9,1.2 \mathrm{~Hz}, \mathrm{Ar}-\mathrm{H}), 7.85\left(1 \mathrm{H}, \mathrm{d}, J 8.2 \mathrm{~Hz}, \mathrm{Ar}-\mathrm{H}^{*}\right), 7.82$ $\left(1 \mathrm{H}, \mathrm{d}, J 8.7 \mathrm{~Hz}, \mathrm{Ar}-\mathrm{H}^{*}\right), 7.78-7.71(1 \mathrm{H}, \mathrm{m}, J$ 8.5, 7.0, $1.4 \mathrm{~Hz}, \mathrm{Ar}-\mathrm{H}), 7.62-7.55(1 \mathrm{H}, \mathrm{m}, \mathrm{Ar}-\mathrm{H}), 7.54-7.50(1 \mathrm{H}, \mathrm{m}, \mathrm{Ar}-$ $\left.\mathrm{H}^{*}\right), 7.43(1 \mathrm{H}, \mathrm{d}, J 8.9 \mathrm{~Hz}, \mathrm{Ar}-\mathrm{H}), 7.40-7.35\left(1 \mathrm{H}, \mathrm{m}, J 7.4 \mathrm{~Hz}, \mathrm{Ar}-\mathrm{H}^{*}\right), 7.12\left(1 \mathrm{H}, \mathrm{d}, J 8.7 \mathrm{~Hz}, \mathrm{Ar}-\mathrm{H}^{*}\right), 4.86(1 \mathrm{H}, \mathrm{s}$, $\left.\mathrm{CH}_{2}{ }^{*}\right), 4.74\left(1 \mathrm{H}, \mathrm{s}, \mathrm{CH}_{2}{ }^{*}\right), 3.04(3 \mathrm{H}, \mathrm{s}, \mathrm{Me}) .{ }^{13} \mathrm{C}$ NMR (DMSO-d $): \delta 174.0,154.1,151.1,144.8,138.4,138.5,136.9$, $136.7,130.8,129.8,129.7,129.2,128.9,128.7,127.5,125.0,124.9,123.8,123.1,116.3,115.8,110.2,110.2$ 91.7, 30.0.

Preparation of $\mathbf{2 1}$ or $\mathbf{2 7}$ via copper-mediated $\mathbf{N}$-formamidation. To the bromo derivative $\mathbf{2 0}$ or $\mathbf{2 6}(0.27 \mathrm{mmol})$ suspended in formamide $(15 \mathrm{~mL}) \mathrm{CuSO}_{4} \times 5 \mathrm{H}_{2} \mathrm{O}(0.68 \mathrm{mmol})$ and $\mathrm{K}_{2} \mathrm{CO}_{3}(1.35 \mathrm{mmol})$ was added. Whole mixture was heated with magnetic stirring at $150{ }^{\circ} \mathrm{C}$ (oil bath) for about $15-25$ hours. After completion the reaction, as indicated by TLC the mixture was cooled and poured into crushed ice with water (20-30 mL). After $30 \mathrm{~min}$. mixture was extracted with DCM. The combined extracts were dried over $\mathrm{MgSO}_{4}$ and concentrated in vacuo. The residue was next subjected to flash chromatography to afford the pure product $\mathbf{2 1}$ or $\mathbf{2 7}$.

$\mathbf{N}$-(4-Methylbenzo[h]quinazolin-6-yl)formamide (21). Mixture of rotamers 2:1*, light yellow solid, yield $47 \%, 30$ $\mathrm{mg}, \mathrm{mp} 299-301{ }^{\circ} \mathrm{C} ; \mathrm{R}_{f}$ (AcOEt/DCM 5:1) $=0.38$. FTIR $\left(\mathrm{KBr}, v_{\max }, \mathrm{cm}^{-1}\right) 3223,3075,1719 .{ }^{1} \mathrm{H}$ NMR (DMSO-d 6$): \delta$ $10.71\left(1 \mathrm{H}, \mathrm{s}, \mathrm{NH}^{*}\right), 10.59(1 \mathrm{H}, \mathrm{s}, \mathrm{NH}), 9.32-9.20\left(3 \mathrm{H}, \mathrm{m}, 2 \mathrm{Ar}-\mathrm{H}, \mathrm{Ar}-\mathrm{H}^{*}\right), 8.83(1 \mathrm{H}, \mathrm{d}, J 9.4 \mathrm{~Hz}, \mathrm{CHO}$ ), $8.68(1 \mathrm{H}, \mathrm{s}$, $\operatorname{Ar}-\mathrm{H}), 8.62(1 \mathrm{H}, \mathrm{s}, \mathrm{CHO}), 8.37(1 \mathrm{H}, \mathrm{d}, \mathrm{J} 8.3 \mathrm{~Hz}, \mathrm{Ar}-\mathrm{H}), 8.32\left(1 \mathrm{H}, \mathrm{d}, J 8.1 \mathrm{~Hz}, \mathrm{Ar}-\mathrm{H}^{*}\right), 8.01-7.91\left(2 \mathrm{H}, \mathrm{m}, \mathrm{Ar}-\mathrm{H}, \mathrm{Ar}-\mathrm{H}^{*}\right)$, 7.91-7.86 (3H, m, Ar-H, 2Ar-H*), 2.96 (3H, s, Me*), 2.90 (3H, s, Me). ${ }^{13} \mathrm{C}$ NMR (DMSO-d $): \delta 165.8,164.3,160.9$, $158.5,153.8,153.7,146.2,135.9,132.3,130.3,130.2,129.8,128.8,128.2,127.9,124.9,123.1,122.1,121.5$, 111.8, 111.4, 21.8, 21.6. HRMS (ESI) $\mathrm{m} / \mathrm{z}$ calcd for $\mathrm{C}_{14} \mathrm{H}_{12} \mathrm{~N}_{3} \mathrm{O}: 238.0975$; found $[\mathrm{M}+\mathrm{H}]^{+}:$: 238.0974.

Preparation of benzoquinazolinone derivatives 28 via Pd cross-coupling reaction. An oven dried resealable Schlenk flask which was equipped with a magnetic stirring bar was charged with $\mathrm{Pd}_{2}\left(\mathrm{dba}_{3}(0.062 \mathrm{mmol})\right.$, Binap $(0.062 \mathrm{mmol})$ and freshly distilled toluene $(4 \mathrm{~mL})$. The vessel was evacuated and backfilled with argon, which was repeated of 3 times. After that $\mathrm{Cs}_{2} \mathrm{CO}_{3}(0.62 \mathrm{mmol})$, bromo derivative $28 \mathrm{a}$ or $\mathbf{2 8 b}(0.42 \mathrm{mmol})$ dissolved in toluene $(6 \mathrm{ml})$ and morpholine $\left(1.2 \mathrm{mmol}\right.$ ) was added. The whole mixture was stirred and heated at $100{ }^{\circ} \mathrm{C}$ (oil bath) for 30 hours. After this time the reaction mixture was cooled and diluted with chloroform ( $5 \mathrm{~mL}$ ). The solid was filtered off, washed with chloroform $(2 \mathrm{~mL})$ and the filtrate concentrated in vacuo. The crude product was purified by flash chromatography.

3-Benzyl-6-(morpholin-4-yl)benzo[h]quinazolin-4(3H)-one (28a). White solid, yield: 55\%, $86 \mathrm{mg}, \mathrm{mp} 165-166$ ${ }^{\circ} \mathrm{C} ; \mathrm{R}_{f}\left(\mathrm{DCM} /\right.$ AcOEt 1:1) = 0.72. FTIR $\left(\mathrm{KBr}, v_{\max }, \mathrm{cm}^{-1}\right)$ 3081, 3066, 3032, 2968, 2917, 2915, 2889, 2853, $2826,1678$. ${ }^{1} \mathrm{H} N M R\left(\mathrm{CDCl}_{3}\right): \delta 8.99(1 \mathrm{H}, \mathrm{d}, J 8.2 \mathrm{~Hz}, \mathrm{Ar}-\mathrm{H}), 8.28(1 \mathrm{H}, \mathrm{d}, J 8.2 \mathrm{~Hz}, \mathrm{Ar}-\mathrm{H}), 8.25(1 \mathrm{H}, \mathrm{s}, \mathrm{Ar}-\mathrm{H}), 7.80(1 \mathrm{H}, \mathrm{s}, \mathrm{Ar}-\mathrm{H})$, 7.74-7.66 (2H, m, Ar-H), 7.43-7.27 (5H, m, Bn), $5.28\left(2 \mathrm{H}, \mathrm{s}, \mathrm{CH}_{2}\right), 4.04-3.96(4 \mathrm{H}, \mathrm{m}, \mathrm{Morf}), 3.25-3.11(4 \mathrm{H}, \mathrm{m}$, Morf). ${ }^{13} \mathrm{C} \mathrm{NMR}\left(\mathrm{CDCl}_{3}\right): \delta 161.2,149.3,145.2,143.7,135.9,132.1,131.5,129.2,129.0,128.5,128.3,127.2$, 125.7, 123.8, 119.2, 109.5, 67.5, 53.6, 50.1. HRMS (ESI) $\mathrm{m} / z$ calcd for $\mathrm{C}_{23} \mathrm{H}_{22} \mathrm{~N}_{3} \mathrm{O}_{2}$ : 372.1707; found [M+H] 372.1702 .

\section{Acknowledgements}

This work was partially supported by the University of Lodz. 


\section{Supplementary Material}

Copies of selected ${ }^{1} \mathrm{H}$ and ${ }^{13} \mathrm{C}$ NMR spectra of new compounds, Biology section information (general), Computational details and additional compounds characterization data, Schemes, Tables, Figures can be found in supplementary material in the online version of this article.

\section{References}

1. Michael, J. P. Nat. Prod. Rep. 2007, 24, 223-246.

http://dx.doi.org/10.1039/B612168N

2. Shang, X-F.; Morris-Natschke, S. L.; Liu, Y-Q.; Guo, X.; Xu, X-S.; Goto, M.; Li, J-C.; Yang, G-Z.; Lee, K-H. Med. Res. Rev. 2017, 1-54.

http://dx.doi.org/10.1002/med.21466

3. Salvam, T. P.; Kumar, P. V. Res. Pharma. 2011,1, 1-21.

Online ISSN: 2231-539X

4. Asif, M. Int. J. Med. Chem. 2014, ID 395637, 1-27.

http://dx.doi.org/10.1155/2014/395637

5. Rakesh, K. P.; Darshini, N.; Shubhavathi, T.; Mallesha, N. Organic\&Medicinal Chem. IJ. 2017, 2, 1-5. http://dx.doi.org/10.19080/OMCIJ.2017.02.555585

6. Basu Sujata, T.; Mamta, P.; Priyanka, K. M.; Sonam, S. Indo Glob. J. Pharm. Sci. 2011, 1, 85-98.

7. Duraipandiyan, V.; Al-Dhabi, N. A.; Balachandran, C.; Ignacimuthu, S.; Sankar, C.; Balakrishana, K. BioMed. Res. Int. 2015, ID 727304, 1-7.

http://dx.doi.org/10.1155/2015/727304

8. Singh, S. K.; Patel, J. R.; Dangi, A.; Bachle, D.; Kataria, R. A. J. Med. Plants Stud. 2017, 5, 175-180. Online ISSN: 2320-3362

9. Houck, J.; Ondeyka, D. R.; Zink, D. L.; Inamine, E.; Goetz, M. A.; Hensens, O. D. J. Antibiot. 1988, XLI, 882891.

10. Haynes, S. W.; Gao, X.; Tang, Y.; Walsh, Ch. T. J. Am. Chem. Soc. 2012, 134, 17444-17447. http://dx.doi.org/10.1021/ja308371z

11. Bose, D. S.; Chary, W. V. Synthesis, 2010, 4, 0643-0650. http://dx.doi.org/10.1055/s-0029-1218606

12. Bock, R. M. G.; DiPardo, M.; Rittle, K. E.; Evans, B. E.; Freidinger, R. M.; Veber, D. F.; Chang, R. S. L.; Chen, TB.; Keegan, M. E.; Lotti, V. J. J. Med. Chem. 1986, 29, 1941-1945. http://dx.doi.org/10.1021/jm00160a024

13. Kumar, A.; Sharma, S.; Kiran Bajaj, A.; Sharma, S.; Panwar, H.; Singh, T.; Srivastava, V. K. Bioorg. Med. Chem. 2003, 11, 5293-5299.

http://dx.doi.org/10.1016/S0968-0896(03)00501-7

14. Selvam, P.; Vijayalakshimi, P.; Smee, D. F.; Gowen, B. B.; Julander, J. G.; Day, C. W.; Barnard, D. L. Antivir. Chem. Chemother. 2007, 18, 301-305.

http://dx.doi.org/10.1177/095632020701800506

15. Pandeya, S. N.; Sriram, D.; Nath, G.; De Clercq, E. Pharm. Acta Helv. 1999, 74, 11-17. http://dx.doi.org/10.1016/S0031-6865(99)00010-2 
16. Raju, G. N.; Sai, K. B.; Resshma, V.; Sudarshini, N.; Sowmya, P. L.; Nalini, Y.; Nadendla, R. R. J. Chem. Pharm. Res. 2015, 7, 1279-1287.

Online ISSN: 0975-7384

17. Marzaro, G.; Guiotto, A.; Chilin, A. Expert Opin. Ther. Patents, 2012, 22, 223-252. http://dx.doi.org/10.1517/13543776.2012.665876

18. Tamura, K.; Fukuoka, M. Expert Opin. Pharmacother. 2005, 6, 985-993. http://dx.doi.org/10.1517/14656566.6.6.985

19. Nurwidya, F.; Takahashi, F.; Takahashi, K. J. Nat. Sc. Biol. Med. 2016, 7, 119-123. http://dx.doi.org/10.4103/0976-9668.184695

20. Schettino, C.; Bareschino, M. A.; Ricci, V.; Ciardiello, F. Expert Rev. Resp. Med. 2008, 2, 167-178. http://dx.doi.org/10.1586/17476348.2.2.167

21. Marzo, I.; Naval, J. Biochem. Pharmacol. 2013, 86, 703-710. http://dx.doi.org/10.1016/j.bcp.2013.07.010

22. Coombs, R. V.; Denzer, D. M.; Hardtmann, G. E.; Huegi, B.; Koletar, G.; Koletar, J.; Ott, H.; Junkiewicz, E.; Perrine, J. W.; Takesue, E. I.; Trapold, J. H. J. Med. Chem. 1973, 16, 1237-1245.

http://dx.doi.org/10.1021/jm00269a006

23. Clissold, S. P.; Beresford, R. Drugs 1987, 33, 478-502. http://dx.doi.org/10.2165/00003495-198733050-00004

24. Falotico, R.; Moore, J. B.; Bandurco, V.; Bell, S. C.; Levine, S. D.; Tobia, A. J. Drug Dev. Res. 1988, 12, 241257.

http://dx.doi.org/10.1002/ddr.430120307

25. Bandurco, V. T.; Schwender, Ch. F.; Bell, S. C.; Combs ,D. W.; Kanoija, R. M.; Levine, S. D.; Mulvey, D. M.; Appollina, M. A.; Reed, M. S.; Malloy, E. A.; Falotico, R.; Moore, J. B.; Tobia, A. J. J. Med. Chem. 1987, 30, 1421-1426.

http://dx.doi.org/10.1021/jm00391a026

26. Nowak, M.; Malinowski, Z.; Jóźwiak, A.; Fornal, E.; Błaszczyk, A.; Kontek, R. Tetrahedron, 2014, 70, 51535160.

http://dx.doi.org/10.1016/j.tet.2014.05.117

27. Nowak, M. ; Malinowski, Z. ; Fornal, E. ; Jóźwiak, A. ; Parfieniuk, E. ; Gajek, G. ; Kontek, R. Tetrahedron, 2015, 50, 9463-9473.

http://dx.doi.org/10.1016/i.tet.2015.10.049

28. Malinowski, Z.; Fornal, E.; Sierocińska, B.; Czeczko, R.; Nowak, M. Tetrahedron, 2016, 72, 7942-7951. http://dx.doi.org/10.1016/j.tet.2016.10.022

29. Turnbull, K.; Sun, C.; Krein, D. M. Tetrahedron Lett. 1998, 39, 1509-1512. http://dx.doi.org/10.1016/S0040-4039(98)00069-0

30. Clark, R. D.; Muchowski, J. M.; Fisher, L. E.; Flippin, L. A.; Repke, D. B.; Souchet, M. Synthesis, 1991, 10, 871878.

http://dx.doi.org/10.1055/s-1991-26597

31. Pace, V.; Holzer, W.; Olofsson, B. Adv. Synth. Catal. 2014, 356, 3697-3736. http://dx.doi.org/10.1002/adsc.201401093

32. Diehl, J.; Brückner, R. Eur. J. Org. Chem. 2017, 2, 278-286. http://dx.doi.org/10.1002/ejoc.201601202 
33. Gay, R. L.; Hauser, Ch, R. J. Am. Chem. Soc. 1967, 89, 1647-1651. http://dx.doi.org/10.1021/ja00983a021

34. Kern, N.; Hoffmann, M.; Weibel, J-M.; Pale, P.; Blanc, A. Tetrahedron, 2014, 70, 5519-5531. http://dx.doi.org/10.1016/i.tet.2014.06.106

35. Ostrowski, S.; Wolniewicz, A. M. Chem. Heterocycl. Compd. 2000, 36, 705-713. http://dx.doi.org/10.1007/BF02297680

36. Cheng, X.; Wang, H.; Xiao, F.; Deng, G-J. Green Chem. 2016, 18, 5773-5776. http://dx.doi.org/10.1039/C6GC02319C

37. Conconi, M. T.; Marzaro, G.; Urbani, L.; Zanusso, I.; Di Liddo, R.; Castagliuolo, I.; Brun, P.; Tonus, F.; Ferrarese, A.; Guiotto, A.; Chilin, A. Eur. J. Med. Chem. 2013, 67, 373-383.

http://dx.doi.org/10.1016/i.ejmech.2013.06.057

38. Ferrini, S.; Ponticelli, F.; Taddei, M. Org. Lett. 2007, 9, 69-72. http://dx.doi.org/10.1021/ol062540s

39. Robev, S. K. Tetrahedron Lett. 1983, 24, 4351-4354. http://dx.doi.org/10.1016/S0040-4039(00)88339-2

40. Breukink, K. W.; Krol, L. H.; Verkade, P. E.; Webster, P. M. Recl. Trav. Chim. Pazs-Bas. 1957, 76, $401-414$. http://dx.doi.org/10.1002/recl.19570760505

41. Ramanathan, M.; Liu, S-T. J. Org. Chem. 2017, 82, 8290-8295. http://dx.doi.org/10.1021/acs.joc.7b01325

42. Komati, R.; Jursic, S. Tetrahedron Lett. 2014, 55, 1523-1527. http://dx.doi.org/10.1016/j.tetlet.2014.01.046

43. Press, J. B.; Bandurco, V. T.; Wong, E. M.; Hajos, Z. G.; Kanoija, R. M.; Mallory, R. A.; Deegan, E. G.; McNelly, J. J.; Roberts, J. R.; Cotter, M. L.; Graden, D. W.; Lloyd, J. R. J. Heterocyclic Chem. 1986, 23, 1821-1828. http://dx.doi.org/10.1002/ihet.5570230643

44. Conley, R. A.; Barton, D. L.; Stefanick, S. M.; Lam, M. M.; Lindabery, G. C.; Kasulanis, Ch, F.; Cesco-Concian, S.; Currey, S.; Fabian, A. C.; Levine, S. D. J. Heterocyclic Chem. 1995, 32, 761-770. http://dx.doi.org/10.1002/ihet.5570320312

45. Pham, T. T.; Walden, M.; Butler, Ch.; Diaz-Gonzalez, R.; Perez-Moreno, G.; Ceballoz-Perez, G.; Gomez-Perez, V.; Garcia-Hernandez, R.; Zecca, H.; Krakoff, E.; Kopec, B.; Ichire, O.; Mackenzie, C.; Pitot, M.; Ruiz, M. L.; Gamarro, F.; Gonzalez-Pacanowska, D.; Navarro, M.; Dounay, A. B. Bioorg. Med. Chem. 2017, 27, 36293635.

http://dx.doi.org/10.1016/i.bmcl.2017.07.032

46. Gimeno, A.; Medio-Simon, M.; Ramirez, C.; De Arellano, R.; Asensio, G.; Cuenca, A. B. Org. Lett. 2010, 12, 1900-1903.

http://dx.doi.org/10.1021/ol100595s

47. Wang, H.; Liu, L.; Wang, Y.; Peng, Ch.; Zhang, J.; Zhu, Q. Tetrahedron Lett. 2009, 50, 6841-6843. http://dx.doi.org/10.1016/j.tetlet.2009.09.130

48. Barthel, A.; Trieschmann, L.; Ströhl, D.; Kluge, R.; Böhm, G.; Csuk, R. Arch. Pharm. Chem. Life Sci. 2009, 342, 445-452.

http://dx.doi.org/10.1002/ardp.200800196

49. Kontek, R.; Matławska-Wasowska, K.; Kalinowska-Lis, U.; Kontek, B.; Ochocki, J. Acta Pol. Pharm. Drug Res. 2011, 68, 127-136.

Online ISSN: 0001-6837; PMID: 21485711 